\title{
HUBUNGAN ANTARA KECERDASAN EMOSI DENGAN AGRESIVITAS REMAJA
}

\author{
Djuwarijah \\ Universitas islam indonesia
}

\begin{abstract}
This research was aimed at determining the relationship between emotional intelligence and aggressiveness. Hypotheses was set as follows: there is a relationship between emotional intelligence and aggressiveness. The subject of the research were 150 first and second years Junior High School students of SLTP Muhammadiyah 3 Kolombo, Depok Yogyakarta in 1999/2000 school year. The data collection was done using the questionnaire mothod for the scale of emotional intelligence, whereas the scale of aggressiveness in the narrative form (vignette) to expressed of the aggressiveness. The relationship between emotional intelligence and the aggressiveness used Product Moment analysis. The result of correlation analysis was $-0,402(\rho=0,000)$. This means that the higher the emotional intelligence, the lower the aggressiveness.
\end{abstract}

Key words: emotional intelligence, aggressiveness

\section{PENGANTAR}

$\mathbf{M}$ asa remaja adalah masa transisi d mana individu mengalami perubahan baik fisik, psikis maupun sosial yang tumbuh dari anak-anak menjadi dewasa. Para remaja dalam menghadapi permasalahannya ada yang mampu memenuhi tuntutan dan kebutuhan diri sendiri, akan tetapi ada yang tidak mampu memenuhi tuntutan yang ada di lingkungannya yang sangat cepat bertambah dan berubah.

Perubahan-perubahan sosial yang cepat sebagai konsekuensi modemisasi, industrialisasi dan kemajuan teknologi mengakibatkan perilaku agresif remaja semakin meningkat. Tindak kekerasan remaja di tndonesia sekarang seperti yang banyak dilansir oleh berbagai media telah mencapai tingkat yang membahayakan. Misalnya peristiwa pencurian oleh lima anak Sekolah
Lanjutan Tingkat Pertama di Bandung (Kedaulatan Rakyat, 26 Maret, 2000); perkosaan di daerah Bantul yang dilakukan oleh anak usia 15 tahun karena terpengaruh film dan bacaan porno (Bernas, 6, Februari 2000); d Klaten 2 siswa Sekolah Lanjutan Tingkat Pertama pesta seks (Kedaulatan Rakyat, 30 Maret 2000); d sekitar Pasar Sukoharjo banyak anak tertangkap basah sedang pesta minuman keras saat jam pelajaran sekolah masih bertangsung (Kedaulatan Rakyat, 30 Maret 2000), perkelahian antar pelajar, pembajakan bis; perampokan bahkan pembunuhan, sehingga begitu serombongan pelajar terlihat berkumpul, masyarakat awam pun cenderung menghindar. Inilah citra yang paling jelek terhadap pelajar dan dunia pendidikan sekaligus. Kebanyakan remaja berstatus 
sebagal pelajar adalah individu yang mengalami transisi dari kehidupan anak-anak menuju kehidupan orang dewasa yang ditandai dengan perubahan dan perkembangan bak segi fisik, psikis, dan sosial (Mönks, dkk., 1991).

Agresivitas yang tinggi tersebut menunjukkan bahwa remaja yang terpelajar atau bersekolah belum tentu berhasil dalam kehidupannya. Keberhasilan hidup seseorang selain ditentukan oleh kecerdasan intelektual atau sering disebut intelligence Question (IQ), juga memertukan kecerdasan emosi (EQ). Salovey dan Mayer (dalam Shapiro, 1997) menjelaskan bahwa kecerdasan emosi merupakan kemampuan mengendalikan perasaan dan emosi serta mengarahkan pikiran dan tindakan. Kemampuan tersebut dapat dikembangkan melalul latihan, pengetahuan dan kemauan (Patton, 1998).

\section{DASARTEORI}

Gardner (dalam Goleman, 1996) menyebut istilah kecerdasan emosi dengan istilah kecerdasan intra pribadi dan kecerdasan antar pribadi, adapun definisi dari kedua istilah tersebut adalah sebagai berikut: (a) kecendasan intra pribadi adalah kemampuan yang bersifat korelatif tetapi terarah ke dabm diri sendiri, yang wujudnya berupa kemampuan untuk membentuk suatu model diri sendiri yang teliti dan mengacu pada diri, serta kemampuan untuk menggunakan model tersebut sebagal alat untuk menempuh kehidupan secara efektif, dan (b) kecerdasan antar pribadi adalah kemampuan untuk mernahami orang lain, yang wujudnya berupa pemahaman terhadap apa yang memotivasi mereka, bagaimana mereka bekerja dan bekerịasama dengan sesamasepert kemampuan untuk membedakan dan menanggapi dengan tepat suasana hati, temperamen, motivasi, dan hasrat orang lain.
Kasifikasi komponen kecerdasan emosi menurut Goleman (1999) mencakup: Pertama, kesadaran diri yaitu mengetahui apa yang dirasakan seseorang pada suatu saat dan menggunakannya untuk memandu pengambilan keputusan diri sendiri;; memiliki tolak ukur yang realistis atas kemampuan diri dan kepercayaan diri yang kuat. Kesadaran diri memungkinkan pikiran rasional memberikan informasi penting untuk menyingkirkan suasana hati yang tidak menyenangkan. Pada saat yang bersamaan, kesadaran diri bisa membantu mengelola diri sendiri dan hubungan antar personal serta menyadari emosi dan pikiran sendiri. Semakin tinggi kesadaran diri, semakin pandai dalam menangani perilaku negatif diri sendiri.

Kedua, pengaturan dir yaitu menangani emosi agar berdampak positif terhadap pelaksanaan tugas, peka terhadap kata hati dan sanggup menunda kenikmatan sebelum tercapai suatu tujuan dan mampu menetralisirtekanan emosi. Pengaturan diri ini mencegah kesalahan-kesalahan dan teribat dalam masalah. Kemampuan ini bisa mengendallkan kemarahan, ketergesagesaan dan memungkinkan berfikir sebelum mengambil tindakan.

Ketiga, motivasi diri yaitu menggunakan has rat yang paling dalam untuk menggerakkan dan menuntun menuju sasaran, membantu mengambil inisiatif dan bertindak secara efektif dan mampu bertahan menghadapi kegagalan dan frustrasi. Kunci motivasi adalah memanfaatkan emosi, sehingga mendukung kesuksesan hidup seseorang.

Keempat, empati yaitu merasakan apa yang dirasakan oleh orang lain, mampu memahami perspektif mereka, menumbuhkan hubungan saling percaya dan menyelaraskan diri dengan orang lain. Empati memungkinkan sesorang mengetahui perasaan dan pikiran orang lain. Apabila 
mengembangkan empati yang dibangkitkan oleh pernahaman dan kekecewaan, perasaan dan pikiran orang lain, maka seseorang akan mampu melihat situasi dari perspektif yang lebih luas.

Kelima, keterampilan sosial yaitu mengendalikan emosi dengan baik ketika berhubungan dengan orang lain, cermat mem baca situasi, berinteraksi dengan lancar, memahami dan bertindak bijaksana dalam hubungan antar manusia.

Keterkaitan antara kecerdasan intelektualdan kecerdasan emosional dikemukakan Goleman (1996) yang menyatakan bahwa IQ yang tinggi tidak akan memberikan kesuksesan pada seseorang dalam kehidupan, bila tidak disertai pengolahan emosi yang sehat. Di samping itu, Wimbarti (1998) mengemukakan bahwa kesuksesan hidup banyak ditentukan oleh kemampuan berhubungan dengan orang lain, keuletan, tahan terhadap godaan, optimis, mampu menyesuaikan diri, menghargai perasaan orang lain dan sebagainya. IQ tanpa kecerdasan emosi bisa mencetak nilai bagus pada ujian akan tetapi tidak akan membuat seseorang sukses dalam hidupnya. Goleman (1996) mengatakan bahwa kecerdasan bila tidak disertai dengan pengolahan emosi yang baik tidak akan mengantarkan kesuksesan seseorang, barkan peranan IQ hanya sekitar 20\% untuk menopang kesuksesan hidup seseorang, sedangkan $80 \%$ lainnya ditentukan oleh faktor lain, diantaranya adalah kecerdasan emosi. Menurut Patton (1998), orang yang kecerdasan emosinya tinggi cenderung akan mengalami kesuksesan of tempat kerja.

Menurut Wimbarti (1998) kecerdasan emosi sebenamya bukan hal baru of Indonesia, dalam budaya Jawa olah rașa ini telah dilakukan sejak jaman nenek moyang dahulu dan nilai-nilainya masih digunakan hingga sekarang ini. Nilai-nilai olah rasa budaya Jawa tersebut adalah nilai tenggang rasa, gotong royong, prihatin, dan sebagainya. Konsep ini telah ditulis kembali oleh Salovey dan Mayer (dalam Shapiro, 1997), Goleman (1996) dan Gadner (dalam Goleman, 1996). Gardner (dalam Goleman, 1996) mengemukakan bahwa kecerdasan yang diperlukan dalam menjalin hubungan dengan orang lain meliputi kemampuan memahami orang lain, hal-hal yang memotivasi, mempengaruhi tindakan mereka, dan bagaimana cara bekerjasama dengan mereka. Orangtua berkewajban memberikan bimbingan kecerdasan emosi pada anak, karena kecerdasan emosi ini merupakan salah satu keterampilan yang sangat penting untuk kesuksesan dalam hidup mereka.

Cooper dan Sawaf (1997) menyatakan bahwa kecerdasan emosi adalah suatu fenomena manusiawi secara mendasar ada dalam diri manusia. Seseorang dapat mencapai keberhasilan hidup semaksimal mungkin melalui kecerdasan emosi, karena itu kecerdasan emosi sangat diperlukan oleh anak terutama remaja yang sangat rentan dengan tindakan agresif. Hasil penelitian Gottman (1997) bahwa anak-anak yang bisa mengenali dan menguasai emosinya lebih percaya diri, lebih baik prestasinya dan akan menjadi orang dewasa yang mampu mengendalkan emosinya.

Berbagai bukti empirik membuktikan bahwa delinkuensi remaja berhubungan dengan aspek pengolahan emosionalnya. Setyowati (1999) dari hasil penelitiannya terhadap siswa SMUN 2 Ngaglik dan SMU Colombo kelas II berjumlah 132 terdiri dari 83 perempuan dan 49 laki-laki menemukan bahwa semakin baik taraf kecerdasan emosinya semakin rendah kecenderungan berperilaku delinkuen, sebaliknya bila kecerdasan emosi buruk, maka kecenderungan berperilaku delinkuen akan tinggi. Hasil penelitian Gottman (1999) menunjukkan bahwa kecenderungan jangka panjang anak 
secara rata-rata merosot dalam keterampilan emosional. Rata-rata mereka menjadi lebih resah dan gampang marah, lebih murung dan tidak bersemangat, lebih depresi dan kesepian, lebh mudah menurutkan kata hati dan tidak patuh. Elfida (1995) menemukan bahwa ada hubungan yang negatif antara kontrol dii dengan kecendenungan berpentaku delinkuen, artinya semakin seseorang mampu mengontrol diri maka semakin keci untuk berperilaku delinkuen. Conger (dalam Kumiawan, 1997) mengatakan bahwa para remaja delinkuen memiliki kontrol diri yang rendah, mereka menunjukkan skor yang tinggi pada sifat impulsif dan pusat kontrol ekstemal dan mereka menunjukkan skor yang rendah pada perkembangan moral dan hati nurani. Menghindari terjadinya agresivitas remaja, maka dipertukan pengawasan ekstemal yaitu pengawasan orangtua, guru dan teman dan pengawasan internal yang datang dari dalam diri dan akan menghasilkan kontrol diri yang merupakan unsur dominan dalam kecerdasan emosi (Goleman, 1996). Penelitian Aziz (1999) juga menemukan bahwa semakin tinggi kecerdasan emosi remaja maka semakin tinggi pula kemampuan remaja menyesuaikan diri dengan lingkungannya.

\section{HPOTESIS}

Berdasar uraian di atas, menunjukkan bahwa kecerdasan emosi dapat digunakan sebagai prediktor perilaku agresif remaja menarik untuk dikaji secara empirik. Hipotesis yang diajukan adalah hubungan antara kecerdasan emosi dengan kecendenungan agresivitas remaja, semakin tinggi kecerdasan emosi remaja maka semakin rendah kecenderungan agresivitas remaja.

\section{METODE}

Varabel yang diteliti dalam penelitian ini adalah kecerdasan emosi dan agresivitas remaja. Kecerdasan enosi adalah suatu kemampuan untuk memahami dan menerapkan kekuatan emosi. Emosi adalah garisgaris kehidupan untuk kesadaran diri dan keselamatan diri yang menghubungkan individu dan orang lain. Emosi memberi informasi tentang hal-hal penting untuk manusia, nilai-nilai, kegiatan dan kebutuhan yang memberi marusia motivasi, keinginan, pengendalan diri dan kegigihan. Kesadaran disi dan pengetahuan tentang emosi memungkinkan individu menyelamatkan keluarga, membina cinta kasih dan sukses dalam kehidupan. Agresivitas adalah setiap bentuk perilaku yang dimaksudkan untuk menyakiti atau menugikan, membahayakan, melukai orang lain baik secara fisik maupun verbal.

Subjek penelitian ini adalah siswa kelas 1 dan 2, Sekolah Lanjutan Tingkat Pertama Muhamadiyah 3 Yogyakarta yang bejumlah 150 siswa. Karakteristik subjek mencakup berstatus sebagai salah satu siswa SLTP Muhamadiyah 3 Yogyakarta, berusia antara 13 sampai 15 tahun, dan duduk di kelas 1 dan2.

Pengukuran kecerdasan emosi dilakukan dengan menggunakan Skala Kecerdasan Emosi yang meliputi 5 aspek yaitu kesadaran diri, pengaturan diri, motivasi diri, empati, dan keterampilan sosial. Teknik penskalaannya menggunakan skala Likert (Alen, 1957). Bobot jawaban pernyataan positif adalah: sangat sesuai $=4$, sesuai $=$ 3 , tidak sesuai $=2$, sangat tidak sesuai $=$ 1. Pemyataan yang negatif pembobotannya dibalik. Skala ini terdiri dari 31 item dengan reliabilitas $=0,9113$ dan koefisien validitas butir bergerak antara 0,3248 sampai 0,7638 .

Agresivitas dalam penelitian ini diukur melalui Skala Agresivitas Remaja yang meliputi aspek agresi fisik aktif langsung. 
agresi fisik aktif tidak langsung, agresi fisik pasif langsung, agresif fisik pasif tidak langsung, agresi verbal aktif langsung, agresi verbal aktif tidak langsung, agresi verbal pasit langsung dan agresi verbal pasit tidak langsung. Penyusunan skala dibuat dalam bentuk cerita (vignette) yaitu deskripsi kongkret dari situasi yang nyata. Pertimbangannya adalah bahwa model cerita ini akan menghadapkan subjek pada kejadian sebenamya yang dapa mendorong terjadinya perilaku agresif. Skala perilaku agresif yang digunakan dalam penelitian hi berjumlah 12 cerita atau vignette. Jawaban yang dianggap paling rendah diberi skor 1 dan jawaban paling tinggi diberi skor 7 . Aspek-aspek yang digunakan dalam penyusunan cerita adalah: (1) kemarahan, yaitu berupa cerita yang menggambarkan keadaan subjek dalam keadaen marah ketika berinteraksi dengan orang lain, (2) frustrasi, yaitu cerita yang menggambarkan adanya gangguan atau kegagaian dalam mencapai tujuan dan (3) ancaman atau serangan, yaitu situasi yang menggambarkan adanya gangguan atau tindakan orang lain yang tidak menyenangkan terhadap diri subjek. Koefisien validitas bergerak antara 0,3414 sampal 0,6646 dengan reliabilitas sebesar0,8265.

Data penelitian dianalisis dengan menggunakan teknik Product Moment, dengan program SPSS for Windows Release 6.O. Analisis ini digunakan untuk menguji hipotesis bahwa kecerdasan emosi berkorelasi dengan agresivitas remaja. Di samping itu, digunakan analisis Stepwise untuk menunjukkan sumbangan tiap aspek dari variabel kecerdasan emosi terhadap agresivilas.

\section{HASIL}

Hasil analisis Product Moment untuk menguji hipotesis yaitu hubungan antara kecerdasan emosi dengan agresivitas, diperoleh $r=-0,402(p=000)$. Hal ini berarti bahwa ada korelasi yang negatif antara kecerdasan emosi dengan agresivltas. Artinya semakin tinggi kecerdasan emosi semakin rendah agresivitas remaja. Hasil anallsis Stepwise menunjukkan sumbangan tiap aspek dari variabel kecerdasan emosi terhadap agresivitas, seperti terlihat dalam tabel di bawah ini.

Tabel. 1

Sumbangan Tlap Aspek Kecerdasen Emosi terhadap Agresivitas

\begin{tabular}{|c|c|c|c|c|}
\hline Model & $\mathbf{R}$ & R Square & $\begin{array}{l}\text { Adjusted R } \\
\text { Square }\end{array}$ & $\begin{array}{c}\text { Std. Error } \\
\text { of The Estimate }\end{array}$ \\
\hline 1. Empati & $0.236^{=}$ & 0.056 & 0.049 & 9.4924 \\
\hline 2. Motivasi & $0.313^{b}$ & 0.098 & 0.085 & 9.3101 \\
\hline 3. Keterampilan Soslal & $0.355=$ & 0.126 & 0.108 & 9.1961 \\
\hline 4. Kesadaran Diri & $0.392^{d}$ & 0.154 & 0.131 & 9.0776 \\
\hline
\end{tabular}


Aspek kesadaran diri memberikan sumbangan paling besar di antara aspek yang lain yaitu sebesar $15,4 \%$, diikuti aspek keterampilan sosial $12,6 \%$, motivasi $9,8 \%$, dan empati 5,6.

\section{PEMBAHASAN}

Hasil penelitian menunjukkan hubungan yang signifikan ( $p<0,01$ ), artinya kecerdasan emosi mempunyai hubungan yang negatif dengan agresivitas remaja. Agresivitas remaja dapat diminimalkan intensitasnya apabila remaja memiliki kecerdasan emosi yang tinggi dari orang tuanya. Kecerdasan emosi memberikan sumbangan efektif sebesar $18,4 \%$ dalam menurunkan tingkat agresivitas pada remaja. Individu yang memiliki kecerdasan emosi tinggi menunjukkan agresivitas yang rendah, mempunyai toleransi dan simpati, menganggap serangan sebagai ketidaksengajaan.

Hasil penelitian ini mendukung hasil temuan Aziz (1999), Setyowati (1999), bahwa semakin bak taraf kecerdasan emosi anak semakin rendah kecenderungan berperilaku delinkuen. Penelitian ini juga didukung oleh Conger (dalam Kumiawan, f997) bahwa remaja delinkuen memiliki kontrol diri yang rendah dan perkembangan moral yang rendah. Penelitian Willis (1981) menunjukkan bahwa salah satu faktor penyebab timbulnya perilaku agresif adalah lingkungan keluarga yang kurang hamonis serta keadaan ekonomi yang rendah karena dapat berpengaruh tenadap perkembangan emosi anak.

Gerald Petterson (dalam Berkowiz, 1995) menyatakan bahwa kondisi yang pen uh tekanan yang ada d keluarga, seperti pengangguran, konfilik suami istri, tingkat pendidikan, penghasilan yang rendah. Berbagai faktor tersebut mempengaruhi pengasuhan anak, sehingga anak cenderung berperilaku agresif di lingkungan sekolah dan masyarakat. Berkaitan dengan hasil penelitian di atas, Freud (dalam Shapiro, 1997) menyatakan bahwa belajar mengendalikan emosi merupakan tanda perkembangan kepribadian yang menentukan apakah seseorang sudah matang. Freud menambahkan bahwa kepribadian anak yang sedang tumbuh dibentuk oleh dua kekuatan yaitu pertama mencari kesenangan can kedua berusaha menghindari rasa sedih dan tidak nyaman. Dikatakan bahwa sernakin tinggi kesadaran anak semakin mampu menimbang berbagai pilkhan dan sernakin besar kemungkinan sukses yang akan diperolehnya dalam mencapai sasaran.

Hasil temuan ini juga sejalan dengan pendapat yang dikemukakan oleh Goleman (1996) bahwa kecerdasan akademik bila tidak disertai kecerdasan emosi tidak akan menghasilkan kesuksesan hidup bagi seseorang, karena IQ tidak memberikan kesiapan untuk menghadapi tantangan atau kesulitan dakam kehidupannya. Kemampuan mengenal emosi menurut Ekowarni (1997) bahwa salah satu cara yang bisa digunakan untuk mengembangkan sikap mampu mengenal emosi adalah mengembangkan sikap empati yaitu dengan melatih sikap peduli pada orang lain dan peka pada kesulitan orang lain serta berusaha untuk membantunya. Para ahli psikoterapi menonjolkan kesadaran emosi sebagai wahana utama untuk mengubah hidup. Para pasien diminta untuk mengungkapkan apa saja yang membuat mereka marah, sedih, merasa bersalah, lalu upaya yang ditempuh adalah mengubah situasi-situasi yang telah mendatangkan perasaan tadi.

Thomas dan Howard (dalam Shapiro, 1997) menyatakan hasil penelitiannya dari 7000 orang Amerika menunjukkan bahwa manfaat empati adalah penyesuaian emosional yang lebih baik, lebih tebuka, lebih berhasil, dan orang yang termotivasi 
mempunyai keinginan seta kemauan untuk menghadapi rintangan. Memotivasi diri sama dengan kerja keras, dan kerja keras akan membuahkan keberhasilan dan kepuasan pribadi.

Hasil penelitian tersebut meyakinkan bahwa kecerdasan emosi mempunyai hubungan yang erat dengan kecenderungan agresi, karena dengan kemampuan pengaturan diri, kesadaran diri, motivasi diri, empati dan keterampilan sosial akan menurunkan intensitas perilaku agresif remaja.

\section{PENUTUP}

Hasil penelitian menunjukkan adanya hubungan antara kecerdasan emosi dengan agresivitas remaja. Hasil ini dapat memberikan informasi bagi orangtua agar berusaha melatih kecerdasan emosi anaknya dari dini terutama keterampilan sosial, kesadaran diri, motivasi dan empati. Bagi guru agar meningkatkan kedisiplinan sekolah supaya siswa dapat lebih mampu mengontrol dan bertanggung jawab terhadap perilakunya sehingga dapat menekan kecenderungan perilaku agresif siswa. Siswa sendiri diharapkan agar dalam setiap aktivitasnya berusaha untuk meningkatkan kesadaran diri, kecakapan sosialnya, memotivasi diri, empati terhadap orang lain serta meningkatkan keimanan dan ketaqwaannya dalam kehidupan untuk menyongsong masa depannya yang sarat dengan kempetisi. Peneliti lain yang tertarik pada kajan ini kiranya dapat menindaklanjuti penelitian ini dengan menyempurnakan penelitian mengenai perilaku agresif dengan memperhatikan faktor-faktor lain yang dapat berpengaruh seperti inteligensi, status sosial ekonomi orang tua, dan sebagainya.

\section{DAFTAR PUSTAKA}

Alex, T.K., 1997. Mengajarkan Emotional Intelligence pada Anak. Terjemaham. Shapiro,L. Jakarta: Buana Printing

Aziz, R. 1999. Hubungan Antara Kecerdasan Emosional dengan Penyesuaian Diri dan Kecenderungan Berperilaku Delikuen pada Remaja, Tesis (tidak diterbitkan). Yogyakarta: Program Pasca Sarjana Psikologi Universitas Gadjah Mada

Azwar,S. 1997. Reliabilitas dan Validitas. Yogyakarta: Pustaka Pelajar Offset

Ekowarni, E. 1993. Kenakalan Remaja: Suatu Tinjauan Psikologi Perkembangan. Buletin Psikologi No.2, 24-27. Yogyakarta: Universitas Gadjah Mada

Elfida, D. 1995. Hubungan Antara Kemampuan Mengontrol Diri dan Kecenderungan Berperilaku Delinkuen pada Remaja. Skripsi. (Tidak diterbitkan) Yogyakarta: Fakultas Psikologi Universitas Gadjah Mada.

Hartati, W.S., 1995. Agresi: Sebab dan Akibatnya. Teriemahan Berkowitz, L. Jakarta: P.T. Pustaka Sinaan Pressindo.

Hermaya. 1996. Kecerdasan Emotional. Ter jemahan: Goleman, D. Jakarta: Gramedia Pustaka Utama

1997. Kiat-Kiat Membesarkan Anak Yang Memiliki Kecerdasan Emosional. Terjemahan: Gottman, J. and Declaire, J. Jakarta: Gramedia Pustaka Utama.

Hermes. 1999. EQ-Kecerdasan Emosional Landasan untuk Meraih Sukses Pribadi dan Karier. Terjemahan: Patton, P. Malang: Mitra Media.

Kantjono. 1998. Executive EQ, Kecerdasan Emosional dalam Kepemimpinan dan 
Organisasi. Terjemahan: Cooper, A.K and Sawaf, A. Jakarta: Gramedia

Khumas, A., Hastjarjo D., dan Wimbarti S. 1997. Peran Fantasi Agresi Terhadap Perilaku Agresif Anak-Anak. , Jurnal Psikologi, Tahun XXIV Nomor 1 Juni. Yogyakarta: Fakultas Psikologi Universitas Gadjah Mada

Kurnlawan, I. N. 1997. Kecenderungan Berperilaku Delinkuen Ditinjau dari Orientasi Religius dan Jenis Kelamin. Skripsi (tidak diterbitkan). Yogyakarta: Fakultas Psikologi Universitas Gadjah Mada

Landung, P.S. 1993. Azas-azas Penelitian Behavioral. Terjemahan Kerllnger, FN. Yogyakarta: Gadjah Mada University Press.

Mönks, F. J. Knoers, A. M. P dan Haditono, S. A. 1994. Psikologi Perkembangan.
Yogyakarta: Gadjah Mada University Press.

Morgan, C. T. 1987. International to Psychology. Tokyo: McGraw Hill-Kogakusha

Setyowati, I. 1999. Hubungan Kecerdasan Emosi dengan Kecenderungan Berperilaku Delinkuen pada Remaja. Skripsi (tidak diterbitkan). Yogyakarta: Fakultas Psikologi Unlversitas Islam Indonesia.

Widodo. 1999. Kecerdasan Emosional Mencapai Prestasi Terjemahar. Goleman Jakarta: Gramedia.

Willis, S.S. 1981. Problem Remaja dan Pemecahannya. Bandung: Angkasa.

Wimbarti, S. 1998. Mengajarkan Kecerdasan Emosional pada Anak Suatu Pandangan Psikologis. Makalah (tidak diterbitkan). Yogyakarta: Fakultas Psikologi Universitas Gadjah Mada. 